Investigating the relationship between firm investment sensitivity and financing constraints with a distinctive Chinese firm data set

\author{
Marco Chen \\ University of Virginia \\ sc9an@virginia.edu
}

May 9, 2017 


\title{
Investigating the relationship between firm investment sensitivity and financing constraints with a distinctive Chinese firm data set
}

\begin{abstract}
This paper demonstrates the non-monotonic relationship between firm investment-cash flow sensitivity and financial constraint by investigating a moderating variable to this relationship. Through a distinctive Chinese firm dataset, this paper suggests the investment in Chinese real estate as an example that moderates the relationship between investment-cash flow sensitivity and financial constraint. The result confirms a non-monotonic relationship between investment-cash flow sensitivity and financial constraint and encourages further investigation into the presence and the endogeneity of moderating variables between the aforementioned relationships.
\end{abstract}

Key Words: investment-cash flow sensitivity, financial constraint, real estate, China, nonmonotonic relationship 


\section{Introduction}

This paper demonstrates a non-monotonic relationship between firm financial constraint level and the firm sensitivity to cash flow in making investing decisions through a distinctive Chinese firm dataset. Existing literature has developed different views on how firm financial constraints, defined as the extent of access to external funding sources, affect firm investmentcash flow sensitivity, defined as the amount of change in firm investment spending given one unit change in firm internally-generated cash flow. Existing empirical finance studies have documented a positive effect of firm cash flow on firm investment spending (Richardson, 2006; Hubbard, 1998). However, there has been no consensus on how the increase or decrease of financial constraints would affect this positive firm investment-cash flow sensitivities. Intuitively, the positive cash flow sensitivity of investments itself can be attributed to the agency cost theory developed by Jensen (1986) and the information asymmetry issues as seen in Myers and Majluf (1984) and Hubbard (1998). The agency cost theory states that when corporate monitoring is weak, managers with free cash flows in excess of firm maintenance and investments with positive NPVs will have the tendency to invest in projects beneficial for management but not for shareholders, which could mean "squandering" resources on projects with negative NPVs (Richardson, 2006, Chen et al., 2016). The information asymmetry theory, on the other hand, suggests that as investors discount the firm external financing capital and make it more costly than firm internal financing capital, in order to take into account the fact that investors are less knowledgeable about the firms than the managers who decided to raise external funds and to compensate the less knowledgeable investors for firm managers' insider knowledge." As a result, firms' external cost of capital will increase and would prompt the firms to invest more in the presence of internal funds that have lower costs of capital. 
Yet there is a lack of such widely accepted explanations regarding the relationships between financial constraints and this positive firm investment-cash flow sensitivities, as different studies have both proposed and empirically documented different results. On one hand, Fazzari, Hubbard, and Petersen (FHP, 1988a) concluded that firms with more financial constraints will have a higher investment-cash flow sensitivity. They proposed that firms with higher external costs of capital must use more of the internal funds to finance their investments rather than to pay out dividends and thus have to take into account their levels of internal cash flows more when making investment decisions. On the other hand, however, Kaplan and Zingales (KZ, 1997) produced a result in the opposite direction of that claimed by FHP using a subset of FHP's dataset and argued that firm financial constraint level might have a nonmonotonic relationship with investment-cash flow sensitivity. KZ suggested that a firm's investment-cash flow sensitivity per se should not be comfortably taken as an indicator of the firm's being financing constrained, contrary to FHP's conclusion.

Recent studies, however, have attempted to advance the investigation. Tirole (2004) and Moyen (2006) have proposed theoretical models suggesting that the effect of financial constraints on firm investment-cash flow sensitivity could be either positive (as in FHP) or negative (as in KZ) instead of monotonic. Almeida and Campello (2007) have, furthermore, incorporated this non-monotonicity in their attempt to empirically validate investment-cash flow sensitivities as a measurement of firm financial constraint on investment. They established asset tangibility as a predictor of the sensitivity and argued that the tangibility is endogenously related to the financial constraints. They argued that an endogenous variable exists that affect both cash flow sensitivities and financial constraints. Whether firm financial constraint and investmentcash flow sensitivity are both influenced by a third confounding or moderating variable is worth 
exploring. Mansour and others (2017), for example, performed regressions on this relationship for the Middle East Gulf Zone company and, through the mixed results, also demonstrated the possibility of moderators, which would support the Almeida and Campello's attempt to validate the existence of a third confounding variable in the relationship between financial constraint and sensitivity measurement. This paper utilizes a dataset with an effective exogenous sorting criteria, namely whether the company has invested in Chinese real estate, to sort companies on their financial constraint and argue for the existence of an at least moderating variable that could significantly modify the relationship between firm financial constraints and firm investment-cash flow sensitivity (hereafter "the relationship.")

\section{Chinese real estate investment as a sorting criteria}

This paper seeks to introduce Chinese real estate investment as a criteria to sort firms on their financial constraint level and to explore whether this criteria moderates the relationship. This study first argues that sorting firm financial constraints based on real estate investment is valid because the spectacular real estate asset appreciation and the highly liquid nature of these assets have made the real estate investment a remarkable windfall for firm cash flows and must have decreased the firm financial constraints.

The idea behind the application of this data set is inspired by a study by Wan \& Zhu (2011). Their works investigated whether investment-cash flow sensitivity can validly correlate with financial constraints by creating a financial constraint measurement based on the Value Added Tax (VAT) reform in China. The tax reform allows taxpayers to recover input VAT on purchases of fixed assets as tax deductions and, as an exogenous shock, arguably created different levels of financial constraints. Looking into the change in investment-CF sensitivity 
after this positive shock on company cash flow that supposedly decreased financial constraints, Wan and Zhu found that cash flow sensitivity increased significantly, thus favoring the KZ argument.

This study believes that there is a strong effect of real estate investment in certain firstand second- tier Chinese city real estate within certain time frame in significantly decreasing firm financial constraints. As Appendix 1 shows, over the whole 10-year period from January 2003 to March 2013, the housing price index for the first-tier cities had a real growth of $13.1 \%$. Among first-tier Chinese cities, the nominal housing price index had an average annual return of 21\% from January 2003 to December 2007 and 17.7\% from January 2009 to March 2013 (Fang et al., 2015). Firms that have real estate investment during the early stage of this appreciation in certain cities are likely to find themselves holding a great investment vehicle with spectacular returns. This will arguably serve as an exogenous shock to the firm cash flow along the time and decrease the firm's need of external funding. This unique and continuous appreciation pattern in the Chinese housing market results from continuous liquidity inflow as a result of several factors detailed below.

The first is the market confidence gained from the policy scheme. Chinese housing has been commodified by policy as a measure to tackle the chronic housing shortage left by the central-planning socialist era. The property development market thus becomes the regulatory instrument to relieve the housing shortage and, through sales of land from local government to property developer, to generate local government revenue (Wu, 2015). Given that local government officials are incentivized by the government promotion criteria to fund capital projects and stimulate local economic growth, and that local government cannot levy sales, property or local income taxes as sources of revenue, local governments found themselves 
increasingly relying on land sales as sources of revenue, which once amounted to $70 \%$ of the city fiscal budget in 2011 on a national average (Fang et al, 2015; see Appendix 2). As local governments continued to use financing vehicles that incorporated bank loans and other securities at the same time to boost investment, their fiscal health has been found to be intertwined with the local housing market. For example, areas with higher expected house price growth are able to issue debt with lower risk premiums. Bonds issued by local investment units from areas that experience greater changes in housing prices also see a corresponding decline in observed yield spreads (Ambrose et al., 2015). As a result, many households in China have been emboldened to believe that the housing market is "too important to fall," and that the central government will be forced to institute policies to pump up the housing market if it was to deteriorate (Fang et al., 2015). The continuous land supply apparently has not overwhelmed the growing demand. As seen in Appendix 3, a real price index that reviews 35 Chinese developed by Wu, Gyourko and Deng (2014) shows that the real constant quality land prices have risen by 335\% from Q1 2004 through Q2 2014, implying a 15.4\% annualized compounding rate similar to that by Fang et al. (2015). Despite of local oversupply in many smaller cities, there has not been systematic housing surplus across the country according to the supply/demand data in Appendix 4 from Wu, Gyourko and Deng (2014).

The second factor is the tendency to use the housing market as a store of value as a result of lacking investment assets and the expected need of savings, which has driven up housing demand (Zhao, 2015). An underlying Chinese household common wisdom is that because of the under-developed social security system, there has historically been a strong preference for savings for the unforeseeable future costs of healthcare, education, and elderly care (Wu, 2015). This is further necessitated by a pension reform that started in 1999 shifting the traditional pay- 
as-you-go (PAYG) system to a mixture of PAYG system and fully funded system, which decreased the replacement rate from around 75\% to only 45\% in 2009 (Zhao, 2015). However, during the first decade of $21^{\text {st }}$ century, Chinese household investment opportunities are limited to low-rate bank deposit and government bond aside from the overly speculative stock market and more recent wealth management products (Zhao, 2015). To Chinse homeowners, housing is an asset that can retain the benefit of value appreciation and is believed to be an effective method to cope with the impact of inflation (Wu, 2015). As housing picked up the trait of being an alternative investment asset, housing buyers are willing to price in the utility of both living and value retention (and creation), thus pushing up the price.

The last factor in hindsight is the expected future income growth, which has also driven up housing demand. It can be seen that despite of the enormous housing price appreciation and strict down payment rules (over 30\%) during the last decade, the participation of low-income households in the housing markets remained steady, though enduring significantly financial burdens. The commonly used price-to-income ratios for low-income Chinese borrowers can be found around 8, which could consume almost half of the servicers' annual income (Fang et al., 2015). The market average in certain cities has gone above 10 historically as well. The household's expected income growth, however, is shown through simple calculation to be crucial in decreasing future price-to-income ratio and determining the willingness to endure such high financial burdens (Fang et al., 2015). This expectation can be seen as being built up from historical trend. Historically Chinese urban household income has had substantial growth. The compound average real annual growth rate of per capita disposable income for urban households reached 8.9\% between 2004 and 2014 (Wu, et al., 2014). This continual growth trend can build lasting household confidence in the future income growth prospect serving to counteract the 
housing burden. It is only suggested here that this expectation in hindsight has worked for the past decade. See Appendix 5 for historical price-to-income ratio data. The indirect policy support, the housing's dual traits of living and investment utility and the expected income growth together contribute to the housing market appreciation in the past decade and enables this study to use real estate investment as financial constraint measurement.

A counterargument against our measurement is that the housing assets are not liquid enough to function as a source of cash flow for firms. However, the continuously upward price index time series in Appendix 6 and the notably less dramatic unsold inventory level time series in Appendix 7 together suggest that the housing market has had quite steady liquidity - it can be inferred that the bid-ask spread had not been widening remarkable. Given that the housing market performance is largely exogenous to the core operation of non-real-estate firms and that the financial impact of this market to firm real estate investment has been undisputable, this paper believes Chinese real estate investment is a valid moderator variable candidate and can be used to sort financially unconstrained companies from constrained ones.

\section{Methodology and hypotheses}

This study used the China Stock Market and Accounting Research (CSMAR) database and drew the year-end data from 1254 firms that had been publicly listed in the broad CSI All Share Index (CSI All Share 000985SH) from 2006 to 2015, excluding financial institutions, real estate companies and companies that are delisted for financial performance reasons during this time period. The study sorted these firms with a dummy variable that equals 1 if the firm financial report indicated investment in non-core-business real estate assets, which has been required by the new Chinese Accounting Standards to be included as a separate accounting entry 
starting from 2007, and equals 0 otherwise. The study followed the FHP regression form of investment expenditure on firm cash flow and Tobin's Q value, all of which were weighted by firm fixed asset value. The regression was added to a politics dummy variable that controlled for potential effect of state ownership on firm investment expenditure, referring to numerous studies that have found that firms with political connections or higher state ownerships could demonstrate lower financing costs and a tendency to have uncommon investment behaviors (Ling et al., 2016; Chen et al., 2016; Xu et al., 2013; Su and Fung, 2013). This dummy variable would equal to 1 if the firm is indicated by CSMAR as a privately owned firms and 0 otherwise. Both real estate and politics dummy variables achieved their sorting through an interaction term with the firm cash flow variable. Following the form of Almeida and Campello (2007) the main regression took the following form.

$$
\begin{aligned}
(I / K)_{i t}=\beta_{0} & +\beta_{1} *(C F / K)_{i t}+\beta_{2} * Q_{i t}+\beta_{3} * \text { Politics }_{i t}+\beta_{4} \\
& * \text { Real Estate Investment }_{i t}+\beta_{5} * \text { Politics }_{i t} *(C F / K)_{i t}+\beta_{6} \\
& * \text { Real Estate Investment }_{i t} *(C F / K)_{i t}+\epsilon_{i t}
\end{aligned}
$$

In this regression I is represented by firm net investment expenditure entry, and CF is represented by firm net income plus non-cash deductions such as depreciation and amortization. $\mathrm{K}$ is the plain vanilla fixed asset book value, and $\mathrm{Q}$ is Tobin's $\mathrm{Q}$ value, or a specific market-tobook ratio value, both calculated in the same way as FHP did. The regression above was performed as a fixed-effect panel data regression through the "plm" package in R. The panel data regression accounted for the fixed firm-specific effects through the individual error component of its error term $\epsilon_{i t}$ (Croissant et al., 2016). The output is different from the regression form above, however, in that the $\beta_{3}$ and $\beta_{4}$ are dropped because the two dummy variables related to 
these coefficients were linearly dependent on the interaction terms $\beta_{5}$ and $\beta_{6}$. See Table 1 for variable correlation matrix and Table 2 for summary statistics.

Table 1. Variable Correlation Matrix

\begin{tabular}{|r|r|r|r|r|}
\hline I & CF & \multicolumn{1}{l|}{ TobinQ } & Prvt & REInvested \\
\hline 1 & -0.46876032 & 0.0003096 & -0.0216 & -0.03756919 \\
\hline-0.46876032 & 1 & -0.000825 & 0.03172 & 0.03448732 \\
\hline 0.00030963 & -0.000824652 & 1 & 0.01277 & -0.01205312 \\
\hline-0.02156293 & 0.031721735 & 0.0127739 & 1 & -0.01505618 \\
\hline-0.03756919 & 0.034487321 & -0.012053 & -0.0151 & 1 \\
\hline
\end{tabular}

Table 2. Full Sample Variable Summary Statistics

\begin{tabular}{|c|c|c|c|c|c|c|c|c|c|c|c|}
\hline vars & n & mean & sd & median & $\min$ & $\max$ & range & skew & kurtosis & Q0.1 & Q0.9 \\
\hline $\mathrm{I} / \mathrm{K}$ & 12540 & 12.11 & 861.86 & -0.15 & -2561.12 & 86810.57 & 89371.69 & 88.55 & 8494.02 & -0.72 & 0.12 \\
\hline $\mathrm{CF} / \mathrm{K}$ & 12540 & -0.27 & 1647.44 & 0.25 & -134041.2 & 123293.9 & 257335.1 & -9.76 & 5997.71 & 0.04 & 1.09 \\
\hline TobinQ & 12540 & 3.16 & 27.51 & 1.96 & 0 & 3001.08 & 3001.08 & 103.53 & 11239.98 & 1.09 & 4.93 \\
\hline
\end{tabular}

It is above all worth noting that, as seen from the summary statistics in Table 2, the data set is present with outliers. In fact, the outliers, uncontaminated by the research methodology or data collection, are so influential that the simple panel data regression outputs would likely be affected. Compare the output in Figure 1 and Figure 2 and notice the scale of y-axis. This will be discussed in later sections.

This study hypothesizes that the non-core business investment in Chinese real estate market would constitute a statistically significant moderating or confounding variable that interferes with the relationship between firm investment-cash flow sensitivity and financial constraints. The hypothesis would be supported if the $\beta_{6}$ is shown to be significant. 
Figure 1. Full Sample Chinese Firm Investment Spending vs. Cash Flow

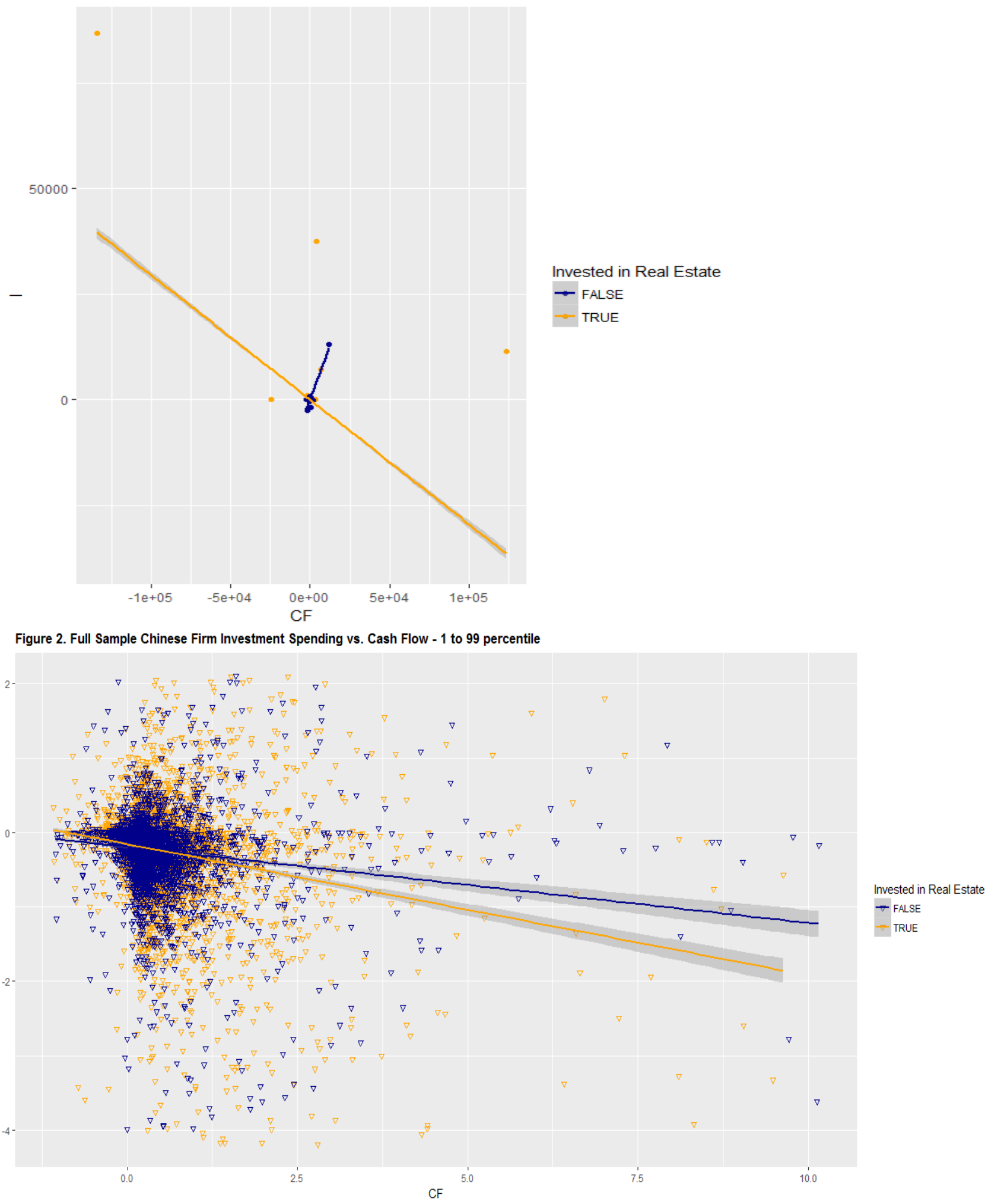




\section{Results and discussion}

Given the limit of topic and methodology in this paper, the panel data regression results and other summary statistics shown below are performed within the $1^{\text {th }}$ to $99^{\text {th }}$ percentile of the $\mathrm{CF} / \mathrm{K}$ data - essentially those in Figure 2. This is based on the rationale that those with abnormal cash flow level might be engaging in a different pattern of activity beyond the scope of discussion in this paper. The regression is performed in a fixed-effect model over a randomeffect one based on a Hausman test. The output supported the hypothesis. As seen in Table 3 below, when all the effect of cash flow on investment spending is taken into account through $\mathrm{CF}$, CF*REInvested (real estate investment dummy variable interaction) and CF*Prvt (Private ownership dummy variable interaction), there appears to be a positive effect of cash flow on firm investment spending, conforming to the existing literature. (I and CF variables are recorded from the cash flow statement and have by default opposite signs, so a negative sum of coefficients would suggest positive effect). More importantly, the coefficients of these three variables together suggest that, if the firm did not invest in real estate and is owned by the state, its investment spending would positively respond to firm internal cash flow level, yet if the firm invested in real estate is and privately owned, the firm would have an investment-cash flow sensitivity much closer to zero, meaning its investment would respond less to the presence of changing internal cash flow. This is strong evidence that the investment in real estate served to moderate the relationship between firm financial constraints and investment-cash flow sensitivity and that this relationship is by nature not monotonic across different situations.

Table 3. Panel Data Regression Output (Perfectly multicollinear variables are dropped.) 


\begin{tabular}{|l|r|r|r|r|}
\hline $\begin{array}{r}\text { Residuals : } \\
\text { Min. }\end{array}$ & 1st Qu. & Median & 3rd Qu. & \multicolumn{1}{l|}{ Max. } \\
\hline-67.252671 & -0.142838 & 0.022467 & 0.167599 & 162.083726 \\
\hline & & & \\
\hline
\end{tabular}

These results could be interpreted in the context of the data. It appears that with real estate investment, firms indeed were able to make investment decisions more freely without considering as much about internal funding level. Seen from the regression output, firms with real estate investment has an investment-cash flow sensitivity of $-0.573(-0.911+0.338)$ comparing to the sensitivity of those without real estate investment (-0.911), meaning that investing in real estate allowed firms to be concerned less about its internal cash flow in investment decisions.

The effect of state ownership on moderating the relationship between sensitivity and firm financial constraint in our sample is also notable. This effect could be examined from the comparison between the regression output of state-owned firm sample and non-state-owned firm sample. As Table 4 and Table 5 revealed, the difference between the investment sensitivity of firms with and without real estate investment is different between the state and non-state firm sample. It appears as if state firms considered more about their cash flow level in investment decisions and might enjoy the relaxing effect of real estate investment more than the private firms. This indirectly contradicted with previous research mentioned above where state firms 
appeared to bear lower external financing costs (Ling et al., 2016; Chen et al., 2016; Xu et al., 2013; Su and Fung, 2013). Two possible explanations are that, first, for the majority of the firms state ownership did have significantly encouraged them to be more "responsible" and consider more regarding internal cash flow level during investment decisions, even at the presence of lower financing costs; second, the counterintuitive results could suggest that while state firms might indeed enjoy less financial constraints as previous research indicated, the level of financial constraint, as $\mathrm{KZ}$ concluded, has a non-monotonic relationship with firm investment-sensitivity cash flow that resulted in the counterintuitive results in Table 4 and 5. In other word, firm financial constraint could be too variable to be a valid measurement of investment sensitivity. The significantly different coefficients of both CF and CF*REInvested in Table 4 and 5 could support this idea.

Table 4. Non-state-owned Firm Panel Data Regression Output

\begin{tabular}{|l|rrr|r|}
\hline Coefficients : & & & \\
\hline & Estimate & Std. Error & $\mathrm{t}$-value & $\operatorname{Pr}(>|\mathrm{t}|)$ \\
\hline CF & -0.0104353 & 0.0931842 & -0.1120 & 0.9108 \\
\hline TobinQ & 0.0012872 & 0.0076881 & 0.1674 & 0.8670 \\
\hline CF:REInvested & -0.1835490 & 0.1280847 & -1.4330 & 0.1519 \\
\hline
\end{tabular}

Table 5. State-owned Firm Panel Data Regression Output

\begin{tabular}{|c|c|c|c|c|c|}
\hline \multicolumn{6}{|l|}{ Coefficients : } \\
\hline & Estimate & Std. Error & t-value & $\operatorname{Pr}(>|t|)$ & \\
\hline $\mathrm{CF}$ & -1.958813 & 0.100483 & -19.494 & $<2.2 \mathrm{e}-16$ & $* * *$ \\
\hline Tobing & 0.063468 & 0.015129 & 4.195 & $2.765 e-05$ & $* * *$ \\
\hline CF: REInvested & 1.790041 & 0.119027 & 15.039 & $<2.2 \mathrm{e}-16$ & $* * *$ \\
\hline--- & & & & & \\
\hline
\end{tabular}

Table 6. Summary Statistics of State and Non-state firms 


\begin{tabular}{|c|c|c|c|c|c|c|c|c|c|c|c|}
\hline \multicolumn{12}{|c|}{ State firms } \\
\hline vars & $n$ & mean & sd & median & $\min$ & $\max$ & range & skew & kurtosis & Q0.1 & Q0.9 \\
\hline I & 7178 & -0.31 & 2.38 & -0.15 & -94.87 & 22.69 & 117.57 & -24.26 & 778.91 & -0.61 & 0.06 \\
\hline $\mathrm{CF}$ & 7178 & 0.42 & 0.71 & 0.23 & -1.08 & 9.63 & 10.72 & 5.54 & 45.51 & 0.06 & 0.91 \\
\hline TobinQ & 7178 & 2.26 & 2.05 & 1.77 & 0 & 87.55 & 87.55 & 15.52 & 527.18 & 1.08 & 3.92 \\
\hline \multicolumn{12}{|c|}{ Non-state firms } \\
\hline vars & $n$ & mean & $s d$ & median & $\min$ & $\max$ & range & skew & kurtosis & Q0.1 & Q0.9 \\
\hline I & 5111 & -0.28 & 3.78 & -0.15 & -86.35 & 184.12 & 270.47 & 18.37 & 1205.34 & -0.83 & 0.18 \\
\hline $\mathrm{CF}$ & 5111 & 0.55 & 1.04 & 0.27 & -1.07 & 10.42 & 11.49 & 4.84 & 30.41 & 0.02 & 1.19 \\
\hline TobinQ & 5111 & 3.43 & 8 & 2.26 & 0 & 393.01 & 393.01 & 30.91 & 1316.39 & 1.13 & 6.03 \\
\hline
\end{tabular}

Table 7. Summary Statistics of Disinvesting Firms

\begin{tabular}{|c|c|c|c|c|c|c|c|c|c|c|}
\hline vars & $\mathbf{n}$ & mean & sd & median & $\min$ & $\max$ & range & skew & kurtosis & se \\
\hline I & 2091 & 0.78 & 4.64 & 0.16 & 0 & 184.12 & 184.12 & 30.53 & 1165.98 & 0.1 \\
\hline $\mathrm{CF}$ & 2091 & 0.63 & 1.15 & 0.29 & -1.08 & 10.42 & 11.5 & 3.95 & 20.29 & 0.03 \\
\hline TobinQ & 2091 & 3.18 & 4.43 & 2.2 & 0 & 88.83 & 88.83 & 10 & 155.34 & 0.1 \\
\hline Prvt & 2091 & 0.5 & 0.5 & 0 & 0 & 1 & 1 & 0 & -2 & 0.01 \\
\hline REInvest & 2091 & 0.67 & 0.47 & 1 & 0 & 1 & 1 & -0.74 & -1.46 & 0.01 \\
\hline
\end{tabular}

However, recall that the dataset has around $2 \%$ of data left out. It is unlikely that these data is interfered by unscientific methods; rather they could represent a new category of firms performing unconventional practice, judged by their abnormal investment spending and operating cash flow changes. This exclusion could modify the existing results significantly given what we see in Figure 1. It is interesting that $2 \%$ of the Chinese firms are behaving almost completely different from other firms. There is also a small portion of firms that have engaged in disinvestment by showing a negative investment spending. (There is a positive mean for the I variable in Table 7.) Looking at the dummy variable rows of Table 7, these firms seem to be equally distributed in state and non-state firms and more than half of them do have real estate investment as well. Firms that have both invested in real estate and disinvested in their core business are particularly worth scrutiny, almost as much as those $2 \%$ of firms excluded earlier for extreme cash flow behaviors. 
While it is clear that the private ownership dummy variable constitutes a moderating variable, an interaction term that modifies the effect strength of another variable, the fact that $2 \%$ of firms likely contains a different effect regarding financial constraint and investment-cash flow sensitivity raises thoughts about whether there might be other endogenous variables that affects both investment-cash flow and financial constraint level, in the same way as asset tangibility demonstrated by Almeida and Campello (2007). This investigation would have to be done through more advanced methods and data such as instrumental variables and switching regression model.

To conclude, this paper successfully established investment in Chinese real estate as a criteria to sort company financial constraint level and as a moderating variable that affects the investment-cash flow sensitivity. The non-monotonic effect of conveyed support to KZ's idea that the relationship between firm financial constraints and investment-cash flow sensitivity is not conveniently straightforward. However, this study demonstrated that there could be other endogenous variables similar to asset tangibility that would account for the change in both firm financial constraints and investment-cash flow sensitivity variables as well as their in-between relationship. As Almeida and Campello (2007) stated, capturing this moderating and the potential non-monotonic endogenous effect could help uncover more information about financing constraints embedded in investment-cash flow sensitivities. 
Acknowledgement: This paper is submitted to the McIntire School of Commerce Global

Commerce Scholar Program. I would like to thank my thesis advisor Professor Zhaohui Chen for

his direction and comments on operationalizing this research and thank Professor Bill Wilhelm

and Dean Chris Wilcox-Elliot for heading the program. I appreciate the help in database

accessibility from Professor Jing Wang and graduate student Sihao Cheng from Southwestern

University of Finance and Economics and Yinghui Zhu from Central University of Finance and

Economics. Special thanks to Yiwen Wu and to Professor Mark White for their tender and

emboldening trust, among many other things.

Appendix 1. Summary Statistics of Housing Return. Fang et al. 2015, pg. 71.

Table 1: Summary Statistics of Housing Return and Growth of GRP and Disposable Income, by Tier of Cities

Panel A: Nominal Growth

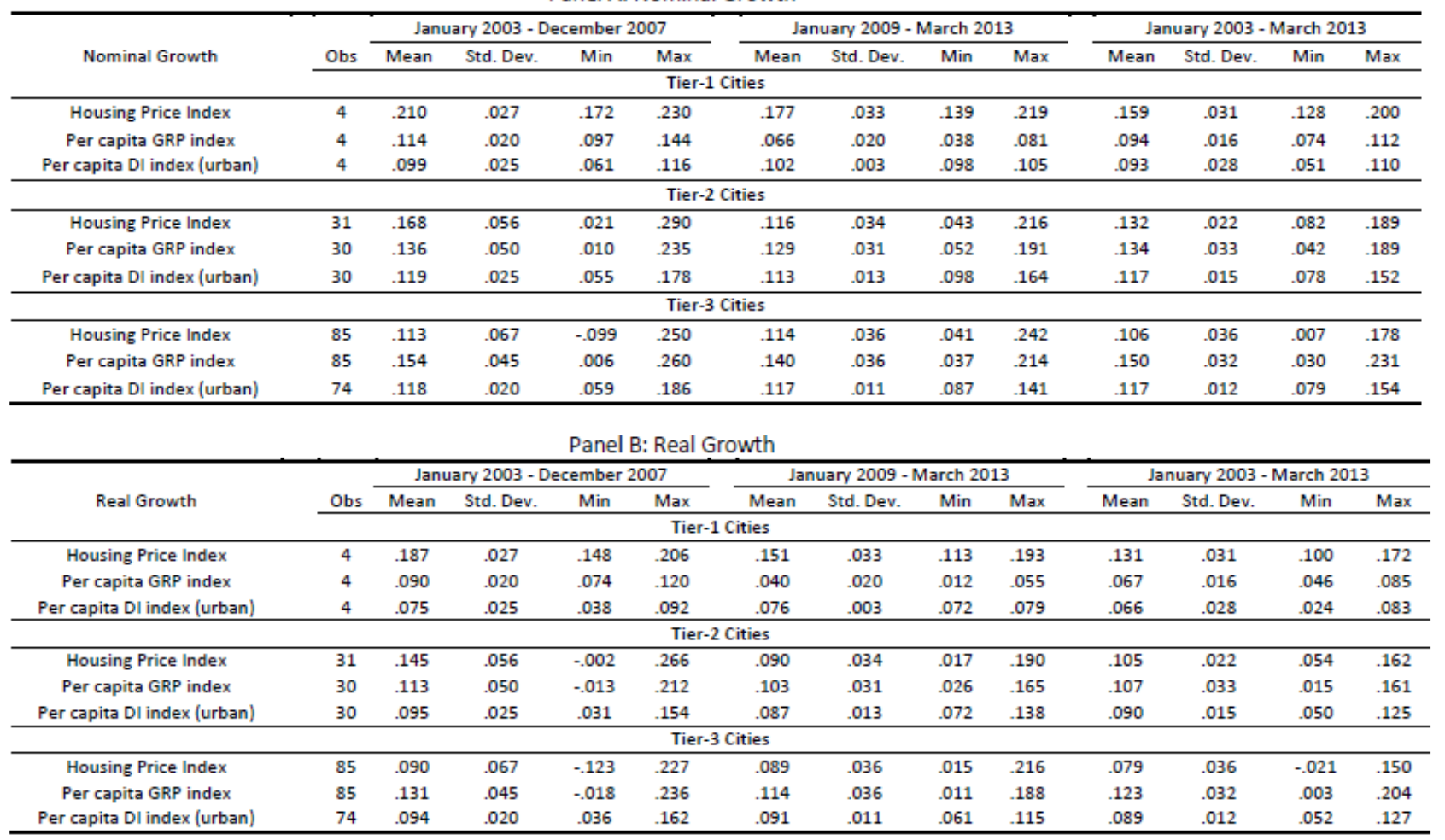


Appendix 2. National Average Percentage of Land Revenue in City Budget. Fang et al., 2015. Pg. 70.

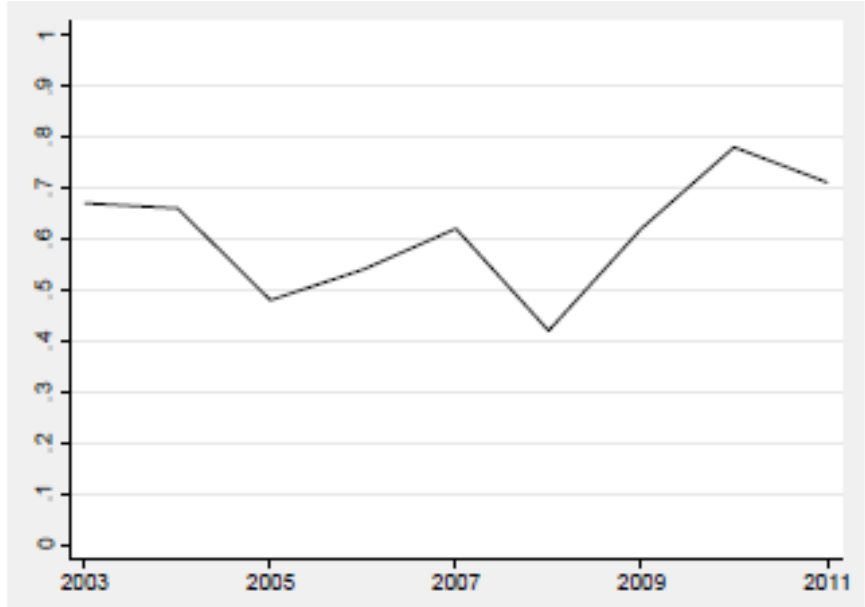

Appendix 3. Chinese National Real Residential Land Price Index based on 35 Markets. Wu et al., 2014. Pg. 40.

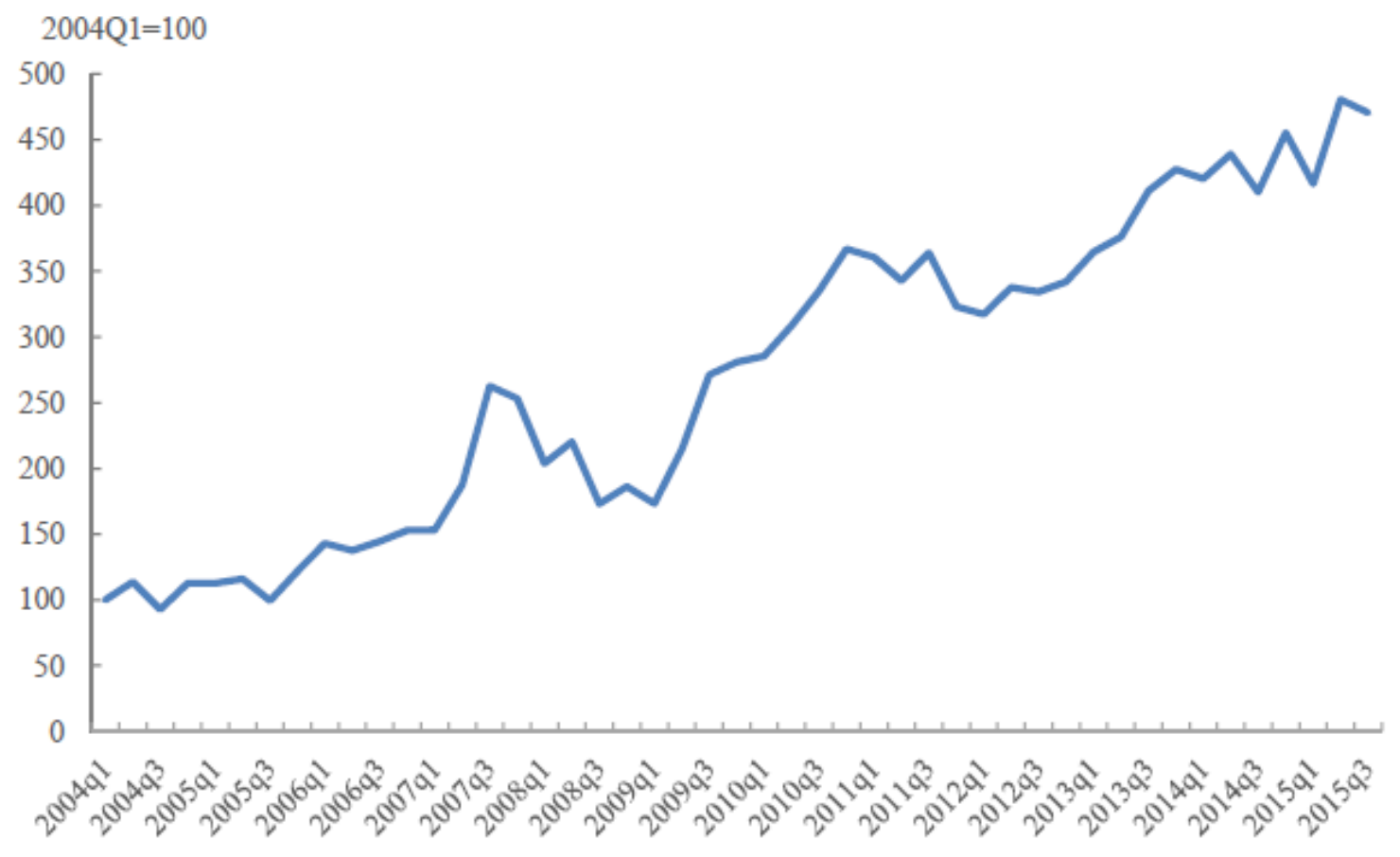


Chen 20

Appendix 4. Supply vs. Demand over Time, National Level and 35 Major Cities. Wu et al., 2014. Pg. 57

\begin{tabular}{|c|c|c|c|c|c|c|c|c|c|}
\hline & \multicolumn{3}{|c|}{$\begin{array}{c}\text { Annual Average Supply } \\
\text { (thousand units) }\end{array}$} & \multicolumn{3}{|c|}{$\begin{array}{c}\text { Annual Average Demand } \\
\text { (thousand units) }\end{array}$} & \multicolumn{3}{|c|}{ Supply-Demand Ratio } \\
\hline & $\begin{array}{l}2001- \\
2010\end{array}$ & $\begin{array}{l}2011- \\
2014\end{array}$ & $\begin{array}{l}2001- \\
2014\end{array}$ & $\begin{array}{l}2001- \\
2010\end{array}$ & $\begin{array}{l}2011- \\
2014\end{array}$ & $\begin{array}{l}2001- \\
2014\end{array}$ & $\begin{array}{l}2001- \\
2010\end{array}$ & $\begin{array}{l}2011- \\
2014\end{array}$ & $\begin{array}{l}2001- \\
2014\end{array}$ \\
\hline Nation & 6739.32 & 10305.54 & 7758.24 & 7768.63 & 8170.90 & 7883.56 & $86.75 \%$ & $126.12 \%$ & $98.41 \%$ \\
\hline Beijing & 243.28 & 194.81 & 229.43 & 281.44 & 216.48 & 262.88 & $86.44 \%$ & $89.99 \%$ & $87.27 \%$ \\
\hline Changchun & 46.35 & 90.89 & 59.07 & 58.43 & 39.84 & 53.12 & $79.33 \%$ & $228.11 \%$ & $111.21 \%$ \\
\hline Changsha & 50.93 & 92.46 & 62.79 & 50.34 & 59.39 & 52.93 & $101.16 \%$ & $155.68 \%$ & $118.64 \%$ \\
\hline Chengdu & 100.11 & 210.19 & 133.32 & 51.7 & 73.26 & 57.86 & $193.63 \%$ & $286.90 \%$ & $230.41 \%$ \\
\hline Chongqing & 223.99 & 398.85 & 273.95 & 128.81 & 175.32 & 142.1 & $173.88 \%$ & $227.50 \%$ & $192.78 \%$ \\
\hline Dalian & 56.46 & 95.13 & 67.51 & 60.04 & 54.66 & 58.51 & $94.04 \%$ & $174.04 \%$ & $115.39 \%$ \\
\hline Fuzhou & 51.62 & 56.22 & 52.93 & 43.3 & 48 & 44.64 & $119.22 \%$ & $117.13 \%$ & $118.58 \%$ \\
\hline Guangzhou & 138.91 & 135.43 & 137.92 & 148.19 & 150.01 & 148.71 & $93.74 \%$ & $90.28 \%$ & $92.74 \%$ \\
\hline Guiyang & 37.54 & 70.92 & 47.08 & 26.35 & 35.77 & 29.04 & $142.45 \%$ & $198.26 \%$ & $162.09 \%$ \\
\hline Haikou & 11.25 & 23.53 & 14.76 & 14.54 & 14.91 & 14.64 & $77.37 \%$ & $157.77 \%$ & $100.76 \%$ \\
\hline Hangzhou & 72.83 & 116.89 & 85.42 & 96.57 & 136.59 & 108.01 & $75.42 \%$ & $85.58 \%$ & $79.09 \%$ \\
\hline Harbin & 105.93 & 143.96 & 116.8 & 83.52 & 46.81 & 73.03 & $126.84 \%$ & $307.54 \%$ & $159.93 \%$ \\
\hline Hefei & 46.24 & 83.61 & 56.92 & 45.14 & 47.15 & 45.71 & $102.45 \%$ & $177.30 \%$ & $124.51 \%$ \\
\hline Hohhot & 41.04 & 46.01 & 39.57 & 22.64 & 21.05 & 22.18 & $181.30 \%$ & $218.63 \%$ & $178.38 \%$ \\
\hline Jinan & 35.43 & 42.65 & 37.5 & 40.67 & 51.34 & 43.71 & $87.14 \%$ & $83.09 \%$ & $85.78 \%$ \\
\hline Kunming & 51.42 & 44.96 & 49.57 & 40.22 & 43.46 & 41.15 & $127.83 \%$ & $103.44 \%$ & $120.47 \%$ \\
\hline Lanzhou & 36 & 31.49 & 34.71 & 21.63 & 30.64 & 24.21 & $166.43 \%$ & $102.75 \%$ & $143.40 \%$ \\
\hline Nanchang & 30.5 & 36.22 & 31.64 & 26.63 & 41.78 & 30.96 & $114.52 \%$ & $86.70 \%$ & $102.20 \%$ \\
\hline Nanjing & 58.59 & 83.2 & 65.62 & 49.5 & 96.36 & 62.89 & $118.37 \%$ & $86.34 \%$ & $104.35 \%$ \\
\hline Nanning & 37.5 & 46.9 & 40.19 & 36.13 & 31.55 & 34.82 & $103.81 \%$ & $148.64 \%$ & $115.42 \%$ \\
\hline Ningbo & 63.78 & 86.51 & 70.27 & 72.22 & 107.83 & 82.39 & $88.32 \%$ & $80.23 \%$ & $85.29 \%$ \\
\hline Qingdao & 66.88 & 87.01 & 72.63 & 45.95 & 61.71 & 50.46 & $145.54 \%$ & $140.99 \%$ & $143.95 \%$ \\
\hline Shanghai & 258.93 & 178.53 & 235.96 & 304.68 & 417.46 & 336.9 & $84.98 \%$ & $42.76 \%$ & $70.04 \%$ \\
\hline Shenyang & 99.42 & 160.28 & 116.81 & 79.84 & 66.1 & 75.92 & $124.52 \%$ & $242.50 \%$ & $153.87 \%$ \\
\hline Shenzhen & 181.08 & 63.87 & 147.59 & 235.25 & 105.6 & 202.82 & $76.97 \%$ & $60.48 \%$ & $72.77 \%$ \\
\hline Shijiazhuang & 41.03 & 68.4 & 48.85 & 39.39 & 53.04 & 43.29 & $104.16 \%$ & $128.97 \%$ & $112.85 \%$ \\
\hline Taiyuan & 37.79 & 59.02 & 43.86 & 28.07 & 33.48 & 29.61 & $134.64 \%$ & $176.31 \%$ & $148.10 \%$ \\
\hline Tianjin & 114.45 & 196.78 & 137.98 & 92.72 & 135.43 & 104.92 & $123.44 \%$ & $145.30 \%$ & $131.51 \%$ \\
\hline Urumqi & 46.25 & 64.22 & 51.38 & 57.69 & 46.19 & 54.41 & $80.16 \%$ & $139.04 \%$ & $94.44 \%$ \\
\hline Wuhan & 68.82 & & & 46.32 & & 52.72 & & & $129.02 \%$ \\
\hline Xiamen & 54.6 & 53.37 & & 53.28 & 31.73 & 47.12 & $102.48 \%$ & $168.20 \%$ & $115.12 \%$ \\
\hline Xian & 59.23 & 116.55 & 75.61 & 58.1 & 58.75 & 58.29 & $101.95 \%$ & $198.37 \%$ & $129.72 \%$ \\
\hline Xining & 16.06 & 59.73 & 28.54 & 19.89 & 26.18 & 21.69 & $80.74 \%$ & $228.12 \%$ & $131.57 \%$ \\
\hline Yinchuan & 36.5 & 57.97 & 42.64 & 21.06 & 24.79 & 22.13 & $173.29 \%$ & $233.82 \%$ & $192.66 \%$ \\
\hline Zhengzhou & 52.66 & 146.17 & 79.38 & 37.62 & 51.6 & 41.61 & $140.00 \%$ & $283.29 \%$ & $190.76 \%$ \\
\hline
\end{tabular}


Appendix 5. Price-to-Income Ratio of Low and Middle Income Mortgage Borrowers in 3 tiers of cities. Fang el al., 2015. Pg. 64.

\section{A. Price-to-Income Ratio in Full Sample}
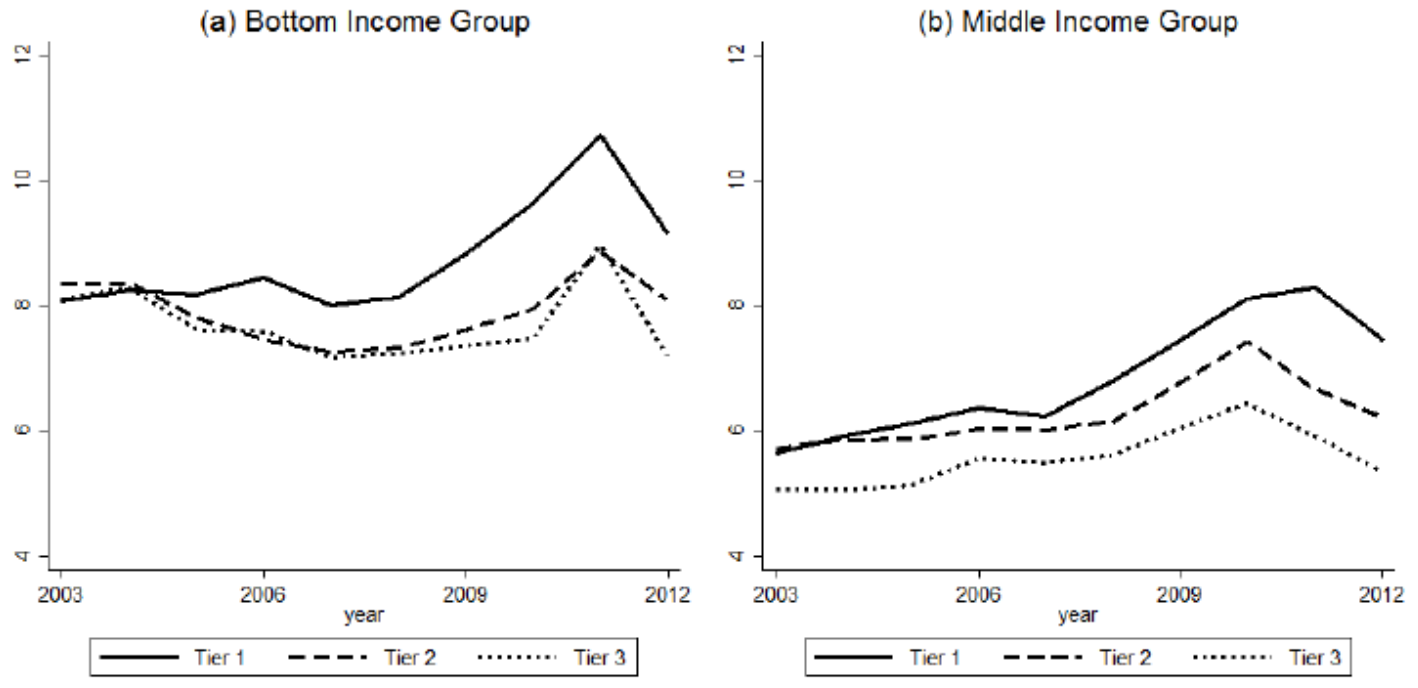
Appendix 6. Housing Price Indices for First-tier Cities by Fang et al., 2015. Pg. 55.
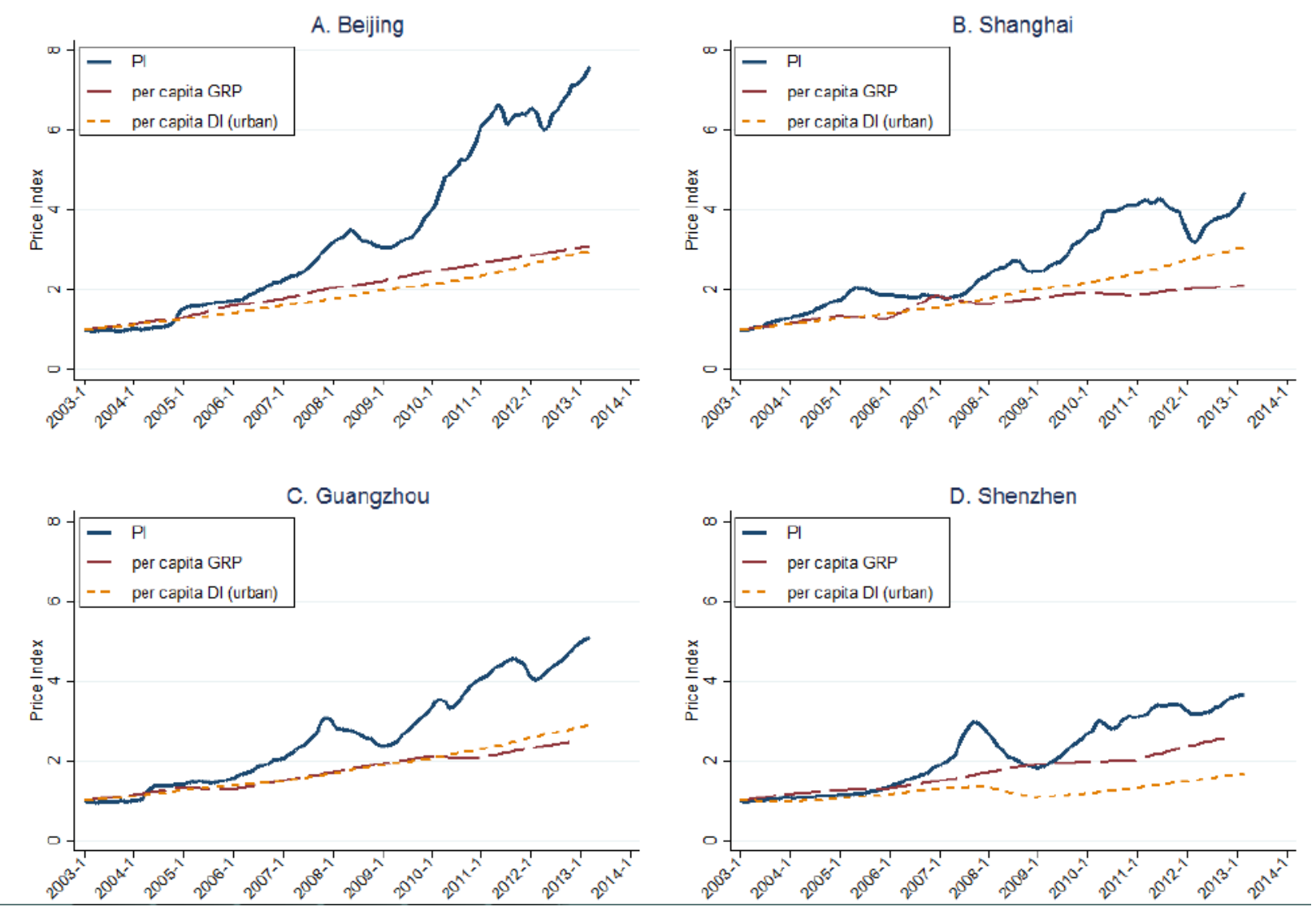
Appendix 7. Unsold Inventory Held by Developers As a Share of Sales Volume in 12 Major Markets, Wu et al., 2015. Pg. 47.
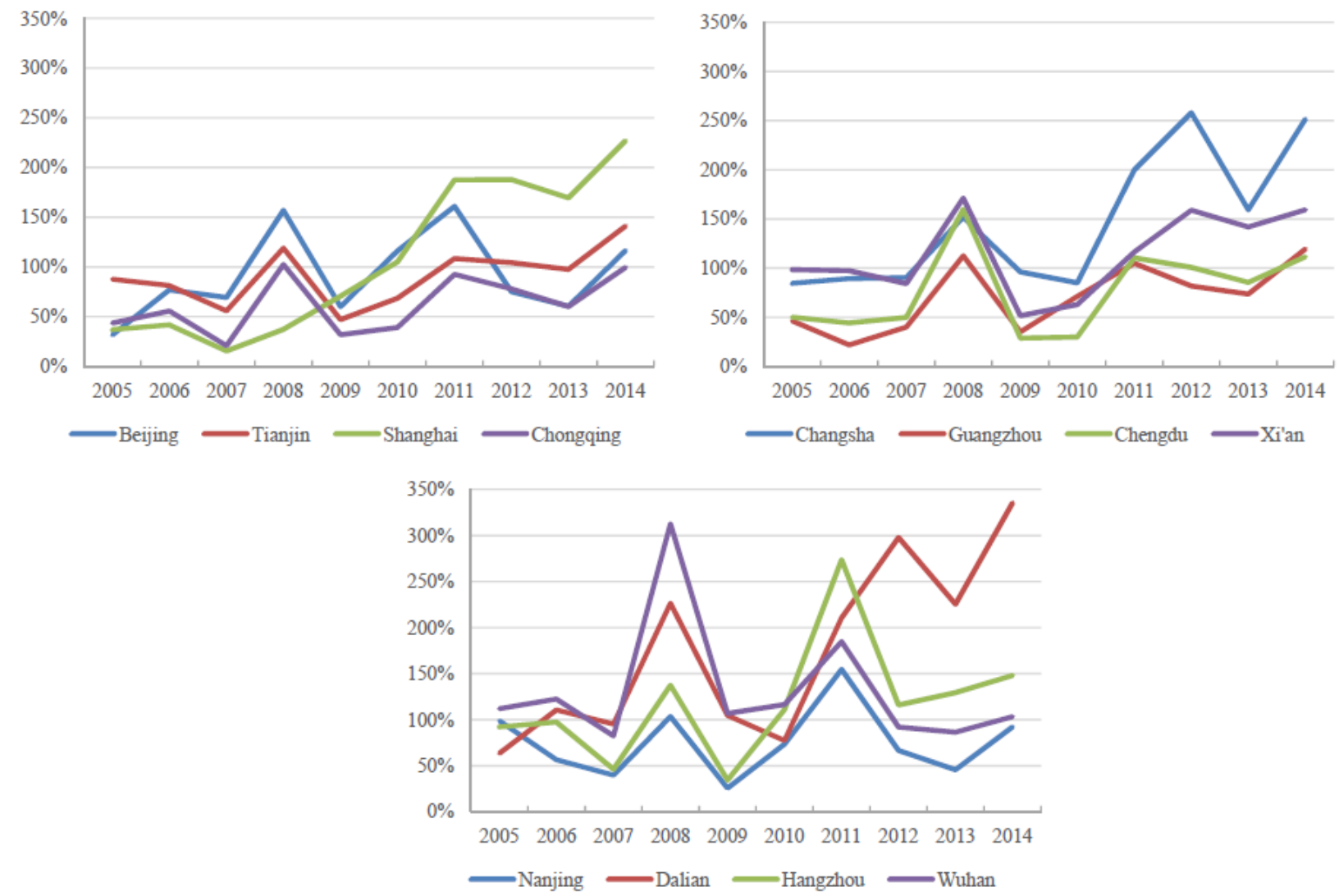

\section{Bibliography}

Allen, Franklin, Jun Qian, and Meijun Qian. "Law, Finance, and Economic Growth in China.” Journal of Financial Economics 77, no. 1 (July 2005): 57-116. doi:10.1016/j.jfineco.2004.06.010.

Almeida, Heitor, and Murillo Campello. "Financial Constraints, Asset Tangibility, and Corporate Investment." The Review of Financial Studies 20, no. 5 (September 1, 2007): 1429-60. doi:10.1093/rfs/hhm019.

Ambrose, Brent W., Yongheng Deng, and Jing Wu. "Understanding the Risk of China's Local Government Debts and Its Linkage with Property Markets." SSRN Scholarly Paper. Rochester, NY: Social Science Research Network, January 28, 2015. https://papers.ssrn.com/abstract=2557031.

Chang, Chun, Xin Chen, and Guanmin Liao. "What Are the Reliably Important Determinants of Capital Structure in China?” Pacific-Basin Finance Journal 30 (November 2014): 87-113. doi:10.1016/j.pacfin.2014.06.001. 
Chen, Xin, Yong Sun, and Xiaodong Xu. "Free Cash Flow, over-Investment and Corporate Governance in China." Pacific-Basin Finance Journal 37 (April 2016): 81-103. doi:10.1016/j.pacfin.2015.06.003.

Deng, Yongheng, Joe Gyourko, and Jing Wu. "The Wharton/NUS/Tsinghua Chinese Residential Land Price Indexes (CRLPI) White Paper." In National University of Singapore Working Paper, 2014. http://whartonrealestate.org/research/papers/full/768.pdf.

Didier, Tatiana, and Sergio L. Schmukler. "The Financing and Growth of Firms in China and India: Evidence from Capital Markets." Journal of International Money and Finance, Macroeconomic and financial policy challenges of China and India, 39 (December 2013): 111-37. doi:10.1016/j.jimonfin.2013.06.021.

Ding, Xiaoya (Sara), Meiying Wu, and Ligang Zhong. "The Effect of Access to Public Debt Market on Chinese Firms Leverage." Chinese Economy 49, no. 5 (October 9, 2016): 327-42. doi:10.1080/10971475.2016.1193387.

Fang, Hanming, Quanlin Gu, Wei Xiong, and Li-An Zhou. "Demystifying the Chinese Housing Boom." Working Paper. National Bureau of Economic Research, April 2015. http://www.nber.org/papers/w21112.

Fazzari, Steven, R. Glenn Hubbard, and Bruce C. Petersen. "Financing Constraints and Corporate Investment." Working Paper. National Bureau of Economic Research, September 1987. http://www.nber.org/papers/w2387.

Hubbard, R. Glenn. "Capital-Market Imperfections and Investment." Journal of Economic Literature 36, no. 1 (1998): 193-225.

Jensen, Michael C. "Agency Costs of Free Cash Flow, Corporate Finance, and Takeovers." The American Economic Review 76, no. 2 (1986): 323-29.

Kaplan, Steven N., and Luigi Zingales. "Do Investment-Cash Flow Sensitivities Provide Useful Measures of Financing Constraints?" The Quarterly Journal of Economics 112, no. 1 (February 1, 1997): 169-215. doi:10.1162/003355397555163.

Knight, John, Alessandra Guariglia, and Sai Ding. "Does China Overinvest? Evidence from a Panel of Chinese Firms." Economics Series Working Paper. University of Oxford, Department of Economics, 2010. https://ideas.repec.org/p/oxf/wpaper/520.html.

Ling, Leng, Xiaorong Zhou, Quanxi Liang, Pingping Song, and Haijian Zeng. "Political Connections, Overinvestments and Firm Performance: Evidence from Chinese Listed Real Estate Firms." Finance Research Letters 18, no. C (2016): 328-33.

Mansour, Walid, Karima Saci, and Saida Khalifa. "How Do Financing Conditions Impact Firm Behavior? Evidence from the Gulf Zone." Emerging Markets Finance \& Trade 53, no. 4 (April 2017): 952-67. doi:10.1080/1540496X.2016.1248555.

Moyen, Nathalie. "Investment-cash Flow Sensitivities: Constrained versus Unconstrained Firms." The Journal of Finance 59, no. 5 (2004): 2061-2092.

Myers, Stewart C. "Capital Structure Puzzle.” Working Paper. National Bureau of Economic Research, July 1984. http://www.nber.org/papers/w1393.

Myers, Stewart C., and Nicholas S. Majluf. "Corporate Financing and Investment Decisions When Firms Have InformationThat Investors Do Not Have.” Working Paper. National Bureau of Economic Research, July 1984. http://www.nber.org/papers/w1396.

Richardson, Scott A. "Over-Investment of Free Cash Flow." SSRN Scholarly Paper. Rochester, NY: Social Science Research Network, February 21, 2006. http://papers.ssrn.com/abstract=884229.

Stulz, ReneM. "Managerial Discretion and Optimal Financing Policies." Journal of Financial Economics 26, no. 1 (1990): 3-27. 
Su, Zhong-qin, and Hung-Gay Fung. "Political Connections and Firm Performance in Chinese Companies." Pacific Economic Review 18, no. 3 (August 1, 2013): 283-317. doi:10.1111/14680106.12025 .

Tan, Wenhao, and Zhenpeng Ma. "Ownership, Internal Capital Market, and Financing Costs." Emerging Markets Finance \& Trade 52, no. 5 (September 2016): 1259-78. doi:10.1080/1540496X.2016.1138815.

Wu, Fulong. "Commodification and Housing Market Cycles in Chinese Cities." International Journal of Housing Policy 15, no. 1 (March 2015): 6-26. doi:10.1080/14616718.2014.925255.

$\mathrm{Wu}$, Jing, Joseph Gyourko, and Yongheng Deng. "Evaluating the Risk of Chinese Housing Markets: What We Know and What We Need to Know." Working Paper. National Bureau of Economic Research, July 2015. http://www.nber.org/papers/w21346.

Xiaoyong Dai, and Liwei Cheng. "Public Selection and Research and Development Effort of Manufacturing Enterprises in China: State Owned Enterprises versus Non-State Owned Enterprises." Innovation: Management, Policy \& Practice 17, no. 2 (April 2015): 182-95. doi:10.1080/14479338.2015.1011053.

Xu, Nianhang, Xinzhong Xu, and Qingbo Yuan. "Political Connections, Financing Friction, and Corporate Investment: Evidence from Chinese Listed Family Firms." European Financial Management 19, no. 4 (September 1, 2013): 675-702. doi:10.1111/j.1468-036X.2011.00591.x.

Zhao, Bo. "Rational Housing Bubble." Economic Theory 60, no. 1 (September 2015): 141-201. doi:10.1007/s00199-015-0889-4. 